\title{
Implementation of Career Guidance Computer and Network Engineering Student in Malang City
}

\author{
Arief Rahman Yusuf \\ Doctoral Student of Vocational Education Program, Post Graduate, State University of Malang \\ J1. Semarang Indonesia 5 Malang \\ aryusuf2589@gmail.com
}

\begin{abstract}
Research aims to obtain field data on the implementation of career guidance in vocational high school computer and network engineering. The method used in the study is a survey method, the population is taken as many as four schools with student number 511. Sampling using method proportional random sampling so that the samples obtained as many as 205 students. Retrieving data using questionnaire. The conclusion of this study is the implementation of career guidance in vocational high schools in Malang City cities is good.
\end{abstract}

Keywords-career guidance, computer, and network engineering student.

\section{INTRODUCTION}

Vocational High School in substance is one vocational institution that is organized to prepare prospective workers in the middle class into business and industry at the same time develop a professional attitude. Indonesian Government Regulation No. 17 of 2010 on Education Management and Implementation of article 76 states the purpose of vocational education is to equip students with the ability of science and technology and vocational skills of the profession in accordance with the needs of the community. Secondary vocational schools as professional secondary education are expected to produce graduates who have the practical skills that can be developed in work without depending on others. In addition, secondary vocational schools were instrumental in meeting the needs and the formation of the student's ability to plan for the future. But the problems facing the school is to see how the student is ready to face the world of business and industry after completing vocational education in secondary schools.

The fact cant is denied is the education in Indonesia has not been able to create quality human resources so that graduates of vocational high schools were oriented to ready to plunge into the world of work only not ready to create their own jobs [1] In the same vein that the implementation of vocational education goes according to its own programs, on the other side of the world of business and industry often complain that the quality of (graduates) do not meet the skill demands competencies expected [2]. Symptoms of mismatch between educational institutions with business and industry world, eventually gave birth to graduates underqualified.In addition, the knowledge and skills they have are not enough to survive in the workplace. Many factors are suspected as the cause, among other things on the side of labor supply (education), from the requester (industry), and also from the graduates themselves [3].
The phenomenon of graduates of vocational education is supported by empirical evidence shows that the total population above 15 years according to the main employment status in Indonesia is still dominated by the Labor/Employee. In February 2017 the carrying amount of the population above 15 years according to the main employment status totaled 125 million people. The amount is in between $38 \%$ to dominate, namely the Labor/Employee/Employee, $18 \%$ on their own, 17\% sought assisted by temporary workers/laborers are not paid, $15 \%$ of family workers (unpaid), $5 \%$ of casual workers in agriculture, $4 \%$ of workers in agriculture, $4 \%$ sought assisted by permanent workers/laborers are paid [4].

More specifically in Malang based on empirical data taken from the department of manpower and transmigration of Malang that registered jobseekers by education level in 2016 that from a total of 1211 people of whom $3 \%$ graduated from primary school, $4 \%$ graduated from junior high schools, $13 \%$ graduated from high school, $10 \%$ graduated from Vocational High School, $24 \%$ graduate diploma, and $27 \%$ of graduates S1. [5]

The results of this survey show that the percentage Vocational High School graduates enter the business and industrial world is still less than a college graduate because graduates Vocational High School in Malang still do not have the competence that meets the requirements of the business and industrial world. Along with vocational school graduates who do not have sufficient competence in the field of specialization, researchers examine the competency areas of expertise Computer Engineering and Networks is one of the majors in Vocational High School which is a model of education based on information technology and communications. In practice in this field are still some problems.

That occurs in areas of competence which this is a computer engineering graduate job opportunities and networking quite a lot, but on the other hand, graduates who can work independently and in accordance with its competence is still very limited. [6] In addition, the gaps between the demands of work that defined the industry's ability to apply the material in Vocational High School, relevance requires efforts from both sides so that the students after graduation can have job readiness to enter the world of business and industry.

The number of vocational school graduates in Malang as the labor supply is sufficient to meet the needs of industry and business world and up from year to year and even tend to be more, but compared with the number of vocational school as a whole, both SMK private and SMK, some supplies are 
found abundant but on the other hand has a shortage of graduates to specific types of expertise and the availability of employment opportunities [7].

The existence of career guidance in schools to foster professionalism in dealing with industry and business world and independence of students with choosing a career that will be lived based capabilities. Through career guidance in vocational students are able to understand himself, his ability level and be able to know the complete picture of the characteristics of his career [8].

Career guidance is the provision of assistance to students by counseling teachers that student or group of students who self-contained and ready to face his career. The scope of career guidance include aspects of the needs assessment with indicators of the ability of students, gifted students, and interests of students, aspect orientation measured by indicators of the introduction of this type of work, introduction of job characteristics, the introduction of compensation for a job, aspects of the individual activities measured by indicators consulting career interests and consulting development students, aspects of intervention counselors measured by indicators directing the careers of students, provide consultation results the students, and provide recommendations students, aspects of internet help measured by indicators searching for information on electronic media and hold a job fair, aspects of the follow-up is measured by indicators aware of career opportunities and determine the ability and skills of students. [9]

\section{METHOD}

This study uses a quantitative approach. Population using purposive sampling with the research subject is class XII student of computer engineering and networks. given the number of students varied between vocational high school in Malang, so that all sub-populations have the same opportunity to become a subject of research, the technique of sampling using proportional random sampling. The results are presented in Table 1.

T ABLE 1. DIST RIBUTION OF POPULATION AND SAMPLE

\begin{tabular}{cccc}
\hline No. & $\begin{array}{l}\text { School of } \\
\text { Sample }\end{array}$ & Population \\
\hline 1 & SMKN 1 Malang & 123 & 49 \\
2 & SMKN 5 Malang & 125 & 50 \\
3 & SMK 10 Malang & 148 & 59 \\
4 & SMK Telkom & 115 & \\
Sandy Putra & 46 & \\
& Total & 511 & \\
\hline & & 205
\end{tabular}

From the measurement results are determined from a population of 511 students to the error rate of $5 \%$ can be produced sample was 205 students.

Instruments in this study using a questionnaire. Instruments The questionnaire is a list of questions developed from indicators based on theories that are relevant to the variables that need to be answered or done by the respondent or students. A questionnaire developed by a Likert scale patterned indicator of value positive and negative patterns of
Never/Disagree, Rarely (about 1-2 times)/Less Agree, Frequent/Agree, Always/Strongly Agree. In the field of education, research instruments generally have two important requirements, namely the validity and reliability [10]. Validity test results were performed using Pearson correlation technique aided by SPSS version 17. With the validity of the test results invalid. Reliability test shows the calculation with the results of the questionnaire unreliable for career guidance.

\section{RESULT}

Career guidance questionnaire consists of 30 questions. In Table 3.1 illustrates that the majority of students found the students' ability to items 1 and 2 categorized as good, gifted students in items 3 and 4 include both categories, the student's interest in items 5 and 6 include both categories, the introduction of this type of work on the students in item 7 and 8 including both categories, the introduction of job characteristics point 9 and 10 include both categories, the introduction of the compensation of the work item 11 and 12 categorized as good, doing consulting career interests point 13 and 14 , including both categories, consult student progress clause 15 and 16 including a category well, directing students' career grains 17 and 18 categorized as good, giving the results of the consultation point 19 and 20 categorized as good, give recommendations to students grains 21 and 22 , including both categories, inform jobs through an electronic medium grain 23 good category and item 24 including the excellent category, the school held a job fair point 25 and 26 good categories, determine appropriate career opportunities talent and interest in grain 27 and 28 categorized as good, knowing the capabilities and skills of item 29 and 30, including both categories. Conclusion career guidance indicates that most of the students' career guidance $(74 \%)$ in both categories(Mean 2,9

6).

\section{DISCUSSION}

Based on the results obtained from the data held in the career guidance vocational education on aspects ranging from the measurement needs of students, the orientation of the work on the students, the activities of individual students, to avoid intervention when making career counselor, get internet help in finding a job, as well as follow up to give a final decision on whether the student is career as expected or in accordance with the results based career guidance process. Good career guidance can lead students in a choice of education, job matching, harmonious and satisfying his personal self. [10]

Career guidance can reflect a person's desire and will also help with making choices realistic about one's career, especially when the motivation of the person's work is created because someone is feeling competent in the required fields in the world of business and industry [11]. Their assistance and career guidance services in secondary vocational schools will have an impact on graduate school students will have the readiness if continuing education to a higher level, work, or trying to self-be entrepreneurs. [12] 
T ABLE II. ANALYSIS CAREER GUIDANCE

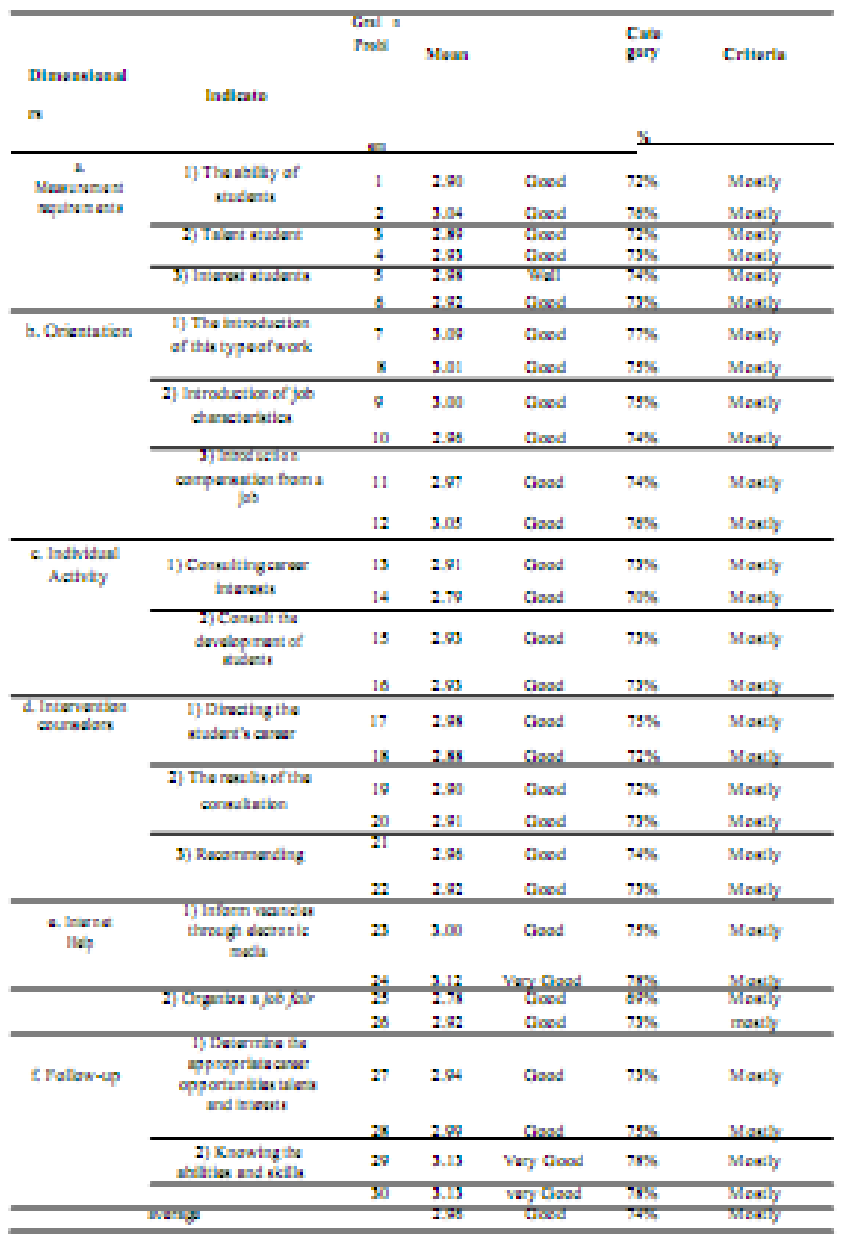

\section{CONCLUSIONS AND RECOMMENDATIONS}

Based on the results of this study concluded that the overall implementation of career guidance in a vocational Malang city is already well underway with results of $74 \%$. Some suggestions are recommended to career counseling, a service of career counseling is necessary to improve the way students are invited to see directly the kinds of jobs that exist in the field, so as to encourage motivation and desire of students to work, teachers can collaborate with its potential and impact upon graduation later students can adjust desire to work and potentials. Need improvement in terms of students' career planning proactively consult with teachers to find a solution that will be taken if problem cant is resolved.

\section{REFERENCES}

[1] Ratnawati, D \& Kuswardani, I. 2010. The maturity of the Vocational and Entrepreneurship Motivation Students in vocational schools(SMK).PsikohumanikaJournal,3 (1): 1-8.

[2] Rahayu, SA 2012. Relations Productive Learning Outcomes and Prakerin with SMK Students Work Readiness in Agam District. Unpublished thesis: Padang State University.

[3] Hanafi, I. 2012. Re-orientation of Vocational Graduates of Vocational Education. Journal of Vocational Education,2 (1): 107-116.

[4] The Central Bureau of Statistics. 2017. Population 15 Years and Over By Main Employment Status 1986 -
2016. Retrieved 28 of September 2017. (https://www.bps.go.id/linkTabelStatis/view/id/971)

[5] Central Bureau of Statistics. 2017. A number of Registered Job Seekers Top Yang According to Education Attainment and Sex in Malang, 20142016.Retrieved 28 of September2017. (https://malangkota.bps.go.id/linkTabelStatis/view/i d/597)

[6] YustinA, A., \& Sukardi, T. 2014. Effect of Vocational Guidance, Achievement Motivation, and Self- Reliance students to Work Readiness Class XII TKJ. Journal of Vocational Education,4 (2): 181-194.

[7] Mone. 2012. Not Evenly, SMK on LaborSupply.(Online)

(http://www.penyelaras an.kemdiknas.go.id/content/ detail/233.html) accessed July 25, 2015

[8] Irsyadi, LM 2012. Influence of Career Guidance and Parenting Parents to Independence Students in choosing a Career in Class XI Power Installation Engineering Department of SMK Negeri 1 Sedayu. UNYJournal.(Online)

(eprints.uny.ac.id/2442/1/Jurnal\%20Penelitian_0750124 1006.pdf).

[9] Zunker, VG 2011. Career Counseling: A holistic approach.New York: Thomson Learning Academic Resource Center.

[10] Arnawa, IK $2012 . \quad$ Determination Training, Entrepreneurship, and Career Guidance Competence against SMK StudentsWork Readiness Group of Technology and Engineering in Buleleng. Journal of Educational Administration,3(2).

[11] Kuijpers, MA, Schyns, B., \& Scheerens, J. (2006).Career competencies for career success. The Career DevelopmentQuarterly,55 (2), 168-178.

[11] Leksana, DM, Wibowo, ME, Tadjri, I. 2013. Module Development of Interactive Multimedia-Based Career Guidance to Enhance Students Career Maturity. Journal of Guidance and counseling.(Online) (Journal.unnes. ac.id/sju/Ni dex.php/jubk/article/ download/1230/1189) 